Relations industrielles

Industrial Relations

\title{
An Economic, Political and Industrial Strategy for Labour
}

\section{Canadian Labour Congress}

Volume 33, numéro 2, 1978

URI : https://id.erudit.org/iderudit/028871ar

DOI : https://doi.org/10.7202/028871ar

Aller au sommaire du numéro

Éditeur(s)

Département des relations industrielles de l'Université Laval

ISSN

0034-379X (imprimé)

1703-8138 (numérique)

Découvrir la revue

Citer cet article

Canadian Labour Congress (1978). An Economic, Political and Industrial Strategy for Labour. Relations industrielles / Industrial Relations, 33(2), 341-350. https://doi.org/10.7202/028871ar
Résumé de l'article

This policy document adopted by the Executive Council of the Canadian Labour Congress was ratified by the 12th Constitutional Convention held in Québec City, April 1978
Tous droits réservés @ C Département des relations industrielles de l'Universite Laval, 1978
Ce document est protégé par la loi sur le droit d'auteur. L'utilisation des services d'Érudit (y compris la reproduction) est assujettie à sa politique d'utilisation que vous pouvez consulter en ligne.

https://apropos.erudit.org/fr/usagers/politique-dutilisation/ 
et scruteraient chaque secteur industriel pour planifier l'expansion ordonnée d'une industrie secondaire, réclameraient une transformation accrue des matières premières au Canada pour y créer des emplois plutôt que de les exporter et de racheter ensuite des articles finis, et aborderaient les problèmes de disparités régionales, de distribution du revenu, d'assurance-chômage, de sécurité sociale et d'impôts.

Le mouvement syndical est tout à fait conscient des difficultés de cette immense tâche. Mais nous n'avons pas le choix. Nous ne pouvons suivre la même route que par le passé.

Le temps est venu pour les syndicats canadiens de dire quel genre de société ils veulent et d'élaborer une stratégie pour y parvenir.

\title{
AN ECONOMIC, POLITICAL AND INDUSTRIAL STRATEGY FOR LABOUR
}

\author{
Canadian Labour Congress
}

This policy document adopted by the Executive Council of the Canadian Labour Congress was ratified by the 12th Constitutional Convention held in Quebec City, April 1978.

The confidence of our people in the political and economic system and in the institutions which are a part of that system has been shaken by the massive and unprecedented intervention of governments on behalf of corporate interests and against the working people and the underprivileged. Because these interventions have been pursued by federal and provincial governments in the absence of economic planning and by a refusal to control corporate power which has grown tremendously because of basic structural changes in the economy, these governments legislated repressive wage controls and severely cut public spending on social programmes.

The powerful economic forces which have been at work within Canada and the world have seriously undermined the assumptions upon which labour has operated historically. Our collective bargaining system, which labour painfully constructed as its first line of defense and its most powerful weapon to gain workers a fair share of the wealth they produce, has been seriously compromised since October 1975. The labour movement must be on guard so that collective bargaining will never again be shackled in the future as it has been by the AIB.The future of collective bargaining is uncertain and vulnerable to attacks by governments only if we, as a labour movement permit it.

For the labour movement to meet this challenge it must have two fundamental things - power and a programme - neither of which is easy or simple to develop. The key to both is leadership and a demonstrated ability by the Canadian Labour Congress to exercise power in the name of its affiliates. 
To this end the Congress has developed a series of papers on the major elements of a national industrial strategy as part of social and economic planning for Canada. This paper is the core paper outlining the fundamental structural changes which have taken place in the economy; the impact these have for the labour movement; and what labour's response must be to meet them.

\section{THE ECONOMIC PROBLEM}

The cracks and the weaknesses of an economic system constructed upon a fragile and narrow resource base; dominated by multinational corporations; and supported by worn out economic theories are reflected in rising inflation, severe loss of jobs and low growth.

A primary reason for the present chaotic state of affairs is the failure of the "free market economy» to fulfill our expectations and do all those things Canadians were promised it would. Our present dilemma is not peculiar to Canada. Rising inflation and unemployment, along with low or no growth are familiar to the other major industrial nations of the western world. The fallacy of the "free market system» and the bakrupt economic theories upon which it was based ended in Canada with the legislating of controls. The AIB was a final desperate deliberate move by governments to convey the impression that they were in command of the economy. After two-and-a- half years of controls which have seriously crippled the Canadian economy it is abundantly clear that new directions must be charted.

This will not happen however, because the government has abdicated its responsibility in facing up to the tremendous concentration of corporate economic power which has taken place since the end of the Second World War. This concentration of corporate power to control supplies, prices, markets and investments has eclipsed the traditional approaches to managing the national economy. This is clearly demonstrated in the government's two major economic policy statements, "The Way Ahead» and «Agenda for Cooperation» which outline government policy and set the course for the country in the years ahead. Both of these policy statements reflect the basic premise that the «free market system » is sound and if left to itself, in combination with a healthy dose of tight fiscal and monetary policy, will steer a cautious course between inflaction and unemployment which will, in the long run, return Canada to a period of economic stability.

Underlying these policy statements by the government is the goal of increasing the private accumulation of capital - increasing the profits and power of the corporations. This, it is alleged, will increase corporate investment, increase efficiency, and therefore reduce inflation and increase employment. And so profits are reinforced by policies such as restricting workers' incomes (wage controls), restricting their collective benefits (social service cut-backs) and increasing corporate after-tax income (tax deferrals, tax incentives, subsidies).

The Congress, however, argues that this approach will not only increase inequality in our society, but - as our recent past has shown - it will also fail to solve the inflation and unemployment problems: wage controls have restricted our incomes, but this control over workers has led to increased unemploy- 
ment along with continued high inflation; profits doubled in the 1971-74 period but this just led to the corporations having more to distribute to stockholders and more to invest outside of Canada; budgets have repeatedly reflected corporate interests, but this corporate welfare has not done anything for th Canadian worker.

It is absurd for the federal governments to pursue the highly conservative philosophy of withdrawing from the management of the economy and leaving it to the private sector to solve the nation's economic ills. Conservative economists have been left gaping at today's problems of high inflation and unemployment, for central to the liberal economic theory of the «free market economy " is that there is a natural equilibrium in the market system tending to full employment and the efficient use of capital and labour. In the hands of governments, fiscal and monetary policies have been the traditional methods of regulating national economies, but these measures only worked where there was a trade - off between unemployment and inflation, which it was assumed could never appear at the same time. Canada's experience in recent years is conclusive proof, as is that of other industrialized nations, that high unemployment and inflation appearing together as economic partners are not temporary aberrations in the economic system. Rather, they are manifestations of basic structural changes brought about by rapid technological change; an ever increasing interdependency in the world's economy; and the rise of large national and multinational corporations. As these changes were developing throughout the world fiscal and monetary powers working on the demand side only, by regulating the money consumers had to spend on goods and services, were becoming less and less effective in managing the economy. The rapid real economic growth of the 60 's and 70's concealed the fundamental weaknesses that were developing. The rise in oil prices exposed these basic weaknesses and the economies of the western industrial world were plunged into a recession.

The arguments of the economists that the problem stems from governments incorrectly applying the existing instruments of economic policy begs the question; for has it not been the case that governments have been following the often conflicting and contradictory advice of those economic theorists? This argument underlines the bankruptcy of current economic thinking, for surely all the governments of the western industrial nations must have committed the same errors to be faced with essentially the same economic problems.

\section{CORPORATE POWER}

A central feature of the present world economy is the presence of large national and multinational corporations which dominate the national economies of the industrial and developing nations. These corporate giants have created a new sector or intermediate level of economic activity which has effectively challenged the traditional fiscal and monetary powers of governments. Each multinational is able to affect the national economy through its individual corporate decision making while effectively shielding itself from government economic policy measures through private market controls.

Of critical importance in the failure of the market system has been the success of these modern industrial giants to control their environment through 
planning, marketing techniques, and price manipulation which has circumvented and destroyed the laws of supply and demand, (by effectively controlling supplies of raw materials and goods), which is the very essence of the market system and traditional liberal economic theory. Contrary to traditional theory, the overproduction of goods does not result in a fall in price, rather it results in inventory buildups and in many cases a rise in price, even in the face of a lower demand, in order to maintain profit margins. This is a major reason why unemployment and inflation appear alongside each other and why corporations lay workers off at the same time that they raise their prices.

These large corporations compete with each other in developing new products; product differentiation; quality and service in order to maintain their share of the market which they share with other equally large corporations. Since these corporations do not fear competition from others entering the field (because of the enormous costs and difficulties of breaking into the captive markets), these well-established corporations set prices on the basis of their strong position in the market. Price leadership has become a well-established and accepted practice and since all these corporations face a market which cannot find substitutes for their product, a rise in prices by one corporation is a signal for the others to raise their prices also. If the government through its fiscal and monetary powers or a wage control programme attempts to reduce what workers can buy (i.e. reduce demand to bring down inflation), the prices charged by these multinationals do not fall because this will not increase profits or gain them a greater share of the market. What they will do is build up inventories and stockpiles and eventually, if the recession is long, lay off workers. But prices do not fall and that is the important factor in the inflationary process; and that is also why the present tight monetary and fiscal policies in combination with wage controls have not reduced inflation, but have increased unemployment and reduced the real incomes of workers.

Furthermore, an increase in demand, even in times of high unemployment and where there is plant and equipment lying idle, brings an inflationary response in price setting in anticipation of this higher demand. And this is where the inflationary expectations enter the picture and where inflation becomes built into the fabric of a nations's economy, because the commodities which these corporations control are primary resources where price increases are reflected throughout the whole economy. It is absurd in this case for the federal government to attack the expectations of workers or the man on the street through wage controls for attempting to protect their standard of living by responding to this new reality.

It is equally absurb to attack the problem through cutbacks in social services or public sector wages when it is obvious that inflationary expectations and the major source of inflation is in the private sector. So long as corporations retain control of the supply side and refuse to cut prices when demand falls, prices will continue to rise and so will inflation. The problem is clear - when demand for their products decline prices do not; on the contrary they may rise; and when demand picks up prices rise in anticipation. This is why inflation has become so persistent in Canada's economy.

Because of this, government's claim that their economic policies are severely compromised, for they argue that an expansionary budget, however 
slight, will set up an inflationary impulse in the pricing policies of this leading sector in the economy - even in times of high unemployment; when plant and equipment are idle; and where stockpiling has occurred. But again, it is economic nonsense for government to follow restrictive economic policies that attack wages and salaries when increasing purchasing power is a must in the short term to get the economy moving. Attacking workers' wages will not reduce inflation as controls have demonstrated. On the contrary, wage controls are reflected in rising inflation and unemployment. In fact, government allowed unemployment to rise in order to limit workers' ability to resist wage controls.

The other major reason why governments control wages grows directly out of the structural changes described above. In order to increase profits corporations have turned to cost competition rather than price competition. This is a natural outgrowth of a process in which corporations do not compete on prices. If they want to increase profit margins and gain a competitive advantage corporations must turn their attention to finding ways of reducing the costs of production. And that is why wages, as a cost of production, have come under direct attack by business and governments. Corporations argue that they cannot compete internationally because competitve costs (read labour costs), are too high in Canada.

Cost competition takes the form of attacks on collective bargaining; on unemployment insurance; on minimum wages; on pensions; on social services because they are indirect wages; and in runaway corporations to exploit low wage countries. Corporations have also intensified research into the development of new labour replacing technologies to gain a competitive cost advantage. The result has been a much more rapid displacement of labour in favour of capital than would be the case where price competition prevailed. Technological unemployment will increase and workers will be its victims unless, as is argued in the paper on "Technological Change and Jobs", the implementation of technological change is harnessed through economic planning.

These multinationals have compounded the problem for trade unioninsts and national economies, for they stand astride national boundaries transferring capital and investment to wherever they find the highest rate of return, regardless of the social chaos they leave in their wake. They determine unilaterally where they will establish new operations; what will be produced; what plants will be shut down; and what plants will survive. This gives them tremendous political power in the affairs of the nation and the world; for national governments compete like regional governments and municipal councils offering tax incentives and tariff protection as inducements.

This private economic decision-making power in the hands of the multinationals can thwart full-employment policies of national governments as well as having tremendous influence on a nation's balance-of-payments position and thus its exchange rate.

As a consequence, national governments have found themselves seriously compromised in the face of these multinationals, in many cases by the lack of the political will to act, of which Canada is a prime example. Furthermore, the absence of an all embracing international agency or of a true international trade union movement to come to grips with the problem of multinational companies presents a challenge for the future. 
The current round of trade talks in Geneva and the public pronouncements by the Canadian government that it is in agreement with the move to lower tariffs to promote trade must be closely watched by the trade unions. To the extent that a move toward freer trade results in greater efficiencies and real economies among the industrialized nations it will only have an impact on inflation if governments take positive action on the pricing and supply policies of these multinationals. The pursuit of freer trade in the absence of proper domestic manpower and social policies will quickly produce an unfavourable political backlash because of its serious dislocating effects among workers and communities which feel the full force of plant shutdowns.

For those trade unions which bargain collectively with these multinationals it would be folly for them not to bargain hard on behalf of their membership for it is the only guarantee that this portion of the corporation's profits will remain in Canada. Furthermore, since government fiscal and monetary policies do not appreciably affect the supply of the products of the multinationals, the prices they charge for them, or their profits, trade unions must assess their bargaining demands in the light of the multinationals' operations.

But this is the exact point where the governments have intervened to prevent trade unions from bargaining wage increases because traditional economic theory argues that the laws of supply and demand $d o$ work and that these corporations $d o$ face competitive price markets. Two-and-a-half years of wage controls in which prices have continued to rise; in which unemployment has climbed in which demand has fallen; in which plant and equipment have been idled is indisputable testimony to the fallacy of the government's economic assumptions.

At the same time that governments have attacked workers' incomes they brought in budgets offering tax incentives and investment tax credits to corporations which did not help the economy, but which ended up in higher corporate profit margins. There is no justice in policies which cause untold human suffering by creating unemployment; which reduce the real incomes of workers; which eliminate social programmes; but which at the same time promote higher prices and profits - profits which are either withheld or invested in low wage countries to return as imports to further rob Canadian workers of jobs.

The concentration of economic power in the hands of national and multinational corporations and financial institutions has left them free of controls to seek higher profits in other countries and to withhold or divert investments. It is the labour movement that is in an exposed and vulnerable position under our present economic and political system.

These are the economic realities which have confronted the labour movement for two-and-a-half years. Because inflation is still increasing; because unemployment is rising; and because Canada is faced with a long period of low economic growth, the attacks on workers' incomes and on collective bargaining will intensify in the future.

\section{THE CHALLENGE CONFRONTING LABOUR}

The labour movement must reject the principles of monopoly ownership where private economic power in the hands of the few is a denial of the funda- 
mental rights of freedom, dignity and justice upon which the trade union movement and social democracy are founded.

The challenge confronting the labour movement grows directly out of the power of corporations to control investments; the number of jobs created; supplies of products and resources; to set prices; to shield themselves from the impact of government fiscal and monetary policies to influence demand and thus the prices they charge for their products; and in effect, to control their markets and national economic policies.

The present economic crisis has been reinforced by the federal government because to do otherwise would demand a political response to control corporations which are its traditional base of political power. As trade unionists, we know this will not happen. Rather, governments have turned their wrath on trade unions and the collective bargaining system. The collective bargaining structure trade unions have so successfully used is under direct political attack and it is obvious serious attempts are being made to destroy it.

Since controls came in, the attack on workers' incomes has taken on a number of new dimensions. Not only have wages been rolled back by the AIB ; but social services which are indirect wages to workers have been drastically cut back; the qualifications for collecting unemployment insurance have been systematically tightened up; public employees have found themselves under concerted attack by governments to restrict the right to strike and to bargain collectively; and pensions have come under fire by the private insurance industry and governments alike. As was pointed out above these attacks grow directly out of the structural changes where corporations compete on costs not prices.

However, the trade union movement's experience with wage controls demonstrates that in the face of the government's intransigence trade unions are at a distinct disadvantage. Politically and economically the trade union movement is severely limited by the federal nature of Canada and restrictive labour legislation that prevents the unorganized from joining trade unions.

The immediate challenge confronting the labour movement is power. To turn aside the challenge of governments and corporations the trade union movement must develop its own countervailing power which it can mobilize and bring to bear on a national basis. To do this more power must be developed on a number of fronts at the same time. Our efforts must be directed to organizing the unorganized to increase labour's base of power. That power must be used to expand the scope of collective bargaining; it must be channelled into electoral support for the New Democratic Party to give labour parliamentary and political influence; and it must be expressed through the Canadian Labour Congress to give labour a strong national voice and the capacity to protect the collective rights of all workers.

\section{THE ROAD TO SOCIAL DEMOCRACY}

The struggle for social democracy will be long and difficult, but there are a number of initial steps which must be taken on a broad front for the labour movement to reach its long term goals. 
1) To achieve this goal the labour movement must develop a unity of purpose and a position of solidarity through a revitalized, strengthened and more relevant Congress.

This represents a formidable task for the trade union movement. In the future the Congress will be called upon to assume responsibilities which it has never had to undertake in the past. These new challenges will demandl a high degree of political awareness, while the development of new policies and approaches will mean a trade union leadership knowledgeable of the economics of the times.

More than ever before the movement in Canada must adapt its institutions to meet the new political and economic realities. Education at all levels of the movement will take on greater and greater meaning for future generations of trade unionists. The ranking officers of the affiliates of the Congress must continue to meet together to discuss, dissect and gauge the impact these changing conditions will have on the labour movement.

The Congress can only be strengthened by a process of demonstrated leadership and by proving to the affiliates and the workers that it is worthy of this responsibility, not through constitutional changes but through confidence and by consent. This is the real source of strength. This transformation will be lengthy but it is the only sure and lasting way in a democratic movement such as ours, for only if labour can successfully marshall its resources in terms of developing greater economic and political clout can it turn aside the economic and political forces arrayed against it.

If the labour movement is to realistically promote a national industrial strategy the Congress must have departments that are working on a continuing basis with the affiliates in each sector of industry. In brief, trade departments that will be capable of providing greater service to the affiliates and which will promote a closer liaison on a continuing basis among the affiliated unions from which greater understanding, unity and solidarity can grow.

2) The labour movement must redouble its efforts in the political arena by increasing its political action programmes and the political awareness of its membership so that trade union power is translated into electoral support for labour's political party - The New Democratic Party.

The analysis of the fundamental structural changes that have taken place in the Canadian and world economies demand that a new direction be plotted to lead Canada out of the present malaise ; one based on social democratic principles. The paralysis in the federal government in terms of understanding the functioning of the new economic order is apparent for all to see. Canada must have real growth to provide jobs and it must have it without inflation. This can only be accomplished through planning and through legislative action which gets at the source of the problem.

3) Our collective bargaining system must be preserved and strengthened, for it is still the most innovative and adaptable system yet developed for protecting the individual and collective rights and freedoms of working people. The collective agreement is the constitution of the work place which the federal government destroyed overnight in favour of the employers. There is no guarantee that future governments will not legislate controls and restrictions to 
destroy the collective bargaining system of workers when the present controls end. It is urgent for the labour movement to begin gathering its collective might on a national basis to meet the attacks which will most certainly be mounted against it - even as it is now being done against the public sector unions. On this issue the labour movement must not permit governments to divide it on the basis of public and private sector. An attack on one will soon be followed by an attack on the other. Only through solidarity will the movement be able to meet the challenge and defeat it.

Collective bargaining is still the primary base from which trade unions must launch their attack on management's rights. There are major areas in health and safety, working conditions, a shorter work-week, security of employment, technological change and layoffs where collective bargaining must be expanded. The attached paper on "Corporate Disclosure» will strengthen collective bargaining and expand it into the whole area of corporate accountability and corporate investment decision making.

In other areas of collective bargaining there may be some merit in moving to broader based bargaining where practicable, but the resolution of collective bargaining problems must remain with labour and management to work out together. There are industrial areas however, where the affiliates, through the Congress, must be prepared to come together to rationalize their collective bargaining programmes to harmonize with labour's interests.

4) Where the movement historically has responded to legislative initiatives by governments it must increasingly emphasize its own alternatives. The labour movement must plan its own programmes and adopt and promote policies in an orderly and well thought-out manner to which business and government must both respond; policies that will lead to our goals of social democracy.

The Canadian Labour Congress, its affiliates, labour councils and federations have a responsability to meet with any and all groups in the community on a continuing basis in order to ensure that the trade union movement's position is heard on vital issues. Our policies and programmes offer positive alternatives which we must pursue with the force and vigour anytime and anyplace.

The power of the labour movement must be felt at all levels of government, agencies, boards and commissions which make decisions that affect the lives of Canadian workers. Labour must continue to attack government policies and programmes that do not meet the needs of the workers. Labour must also criticize publicly why it disagrees.

The Canadian Labour Congress believes that contrary to the accepted political doctrine of most governments in Canada, there are a number of immediate measures that can be taken in the public interest to control multinationals. Legislation calling for full disclosure by corporations on their pricing, production and investment policies (see paper on Corporate Disclosure;) national manpower policies of which a central feature would be the attainment of full employment; and legislative requirements for corporations to retain a percentage of their profits in Canada for job creating investment would go far in making multinationals socially responsible (see paper on Manpower Policies). Again, public accountability of corporations is dependent upon a full knowledge 
of their operations. At the present there is no public accountability on the expenditure of public funds by corporations through tax credits, cost allowances or incentives.

Full disclosure of pricing and investment policies of corporations would help to dampen inflationary price setting agreements because of the force of public opinion and of trade union vigilance on the issue. Furthermore, legislative action and a government dedicated to social and economic planning would zero in on the power of corporations to control the supplies of commodities. An industrial strategy must focus on supply management problems on a selective basis to eliminate bottlenecks and structural problems. An industrial strategy and social and economic planning would represent a real intrusion into the private economic decision-making powers of private industry.

5) Private corporate power must give way to a system of social and economic planning. The present strike by capital has been reflected in cleclining investment and rising unemployment. Workers and communities are bearing the full brunt of the power of corporations to unilaterally withhold investment ; transfer investment abroad; and make decisions that destroy small communities and the future of workers and their families. The private control exercised by the corporate community must be replaced by public accountability.

The present full employment campaign is a good start in this direction but it must be built upon; particularly that part which promotes planning in the economy around a national industrial strategy.

Not only would social and economic planning and a national industrial strategy open up the private decision-making world of the corporations but it would also deal in a positive way in promoting full employment around the concept of a Labour Market Board; it would closely examine each industrial sector to plan the orderly expansion of secondary manufacturing; it would promote greater processing of raw materials in Canada to create jobs rather than exporting them and buying back the manufactured articles; it would deal with the problems of regional disparities, distribution of income, unemployment insurance, social security and taxation.

The labour movement is fully aware of the hazards and difficulties of such an immense task. There are no alternatives - we cannot continue on as we have in the past.

The time has come for Canadian labour to determine what kind of society it wants and to develop the strategy for achieving it. 